\title{
ACCOUNTING AGENDA AND EVALUATION OF ENTERPRISES' ENVIRONMENTAL ACTIVITIES IN THE CZECH REPUBLIC
}

\author{
M. ČERNÍKOVÁ \& O. MALÍKOVÁ \\ Department of Finance and Accounting, Faculty of Economics, Technical University of Liberec, \\ Czech Republic.
}

\begin{abstract}
Environmental protection is an important element of the contemporary economic development. It also brings a new dimension of enterprises' relation to environmental issues. The aim of corporate activities is not only to generate profit but also to satisfy the interests of shareholders. If enterprises want to succeed in such a hard competitive environment, their managements must not forget to consider their relation to the environment. The basic information tool the managers of enterprises may use to get relevant information about the interaction between their enterprise and the environment are accounting modules. The purpose of this paper is to review the preparedness of accounting systems of enterprises in the Czech Republic to catch corporate processes that may be problematic from the environmental point of view. The financial accounting module in the Czech Republic economic environment is firmly bundled with legislation. Pursuant to the applicable provisions of the Czech Act on Accounting and related legislation, environmental information does not need to be tracked. Some information on environment is included in financial statements, but this is usually the case of large corporation only. In connection with the requirements for sustainable development, it is necessary that each entity will closely follow its interaction with the environment. Therefore, the financial but also the managerial accounting modules should be updated to include environmental aspects too. Managers of enterprises will then be able to accurately quantify real costs and revenues associated with environmental issues. Such information could be then used as a basis for analysis of individual corporate activities having some impact on the environment as well as for planning of goals in this area. The management of enterprises should also introduce a system of indicators for the evaluation of environmental aspects within the scope of corporate processes. The paper also covers the case study of the Czech company engaged in the manufacture of aluminum alloy casts. The case study analyzes current options for tracking the selected environmental aspects in managerial and financial accounting systems. The case study further suggests some indicators to evaluate such activities.

Keywords: Corporate management, environmental accounting, environmental indicators, environmental profile of an enterprise, financial accounting, financial analysis, financial statements, managerial accounting.
\end{abstract}

\section{INTRODUCTION}

The end of the 20th century brought the idea of sustainable development. This idea assumes economic growth, but in due consideration of social and environmental conditions. In the context of sustainable development, an emphasis has been more increasingly placed on the mutual interaction between enterprises and the environment. Enterprises have always - with their industrial activities - caused some harm to the environment. However, the resulting negative externalities are reflected in the company costs only partially [1]. Through its environmental protection policy, the government implements into the national economy various administrative or legislative provisions that should help to protect the environment. These instruments obviously affect the economy of companies, but the negative footprint of these companies remains rather untouched [2]. The socially responsible companies deal with this issue on a proactive basis, striving after opportunities and directions towards more sustainable environment. Within the scope of these rather voluntary approaches, ISO certifications in the field of environmental protection are often realized in such companies and various environmental information assessed using a wide range of voluntary tools and activities. The aim of such activities is to establish an information platform that would reflect the companies' environmental behavior. The collected information is evaluated, analyzed and used by company 
management for the development of the plan aimed at the improvement of company's environmental profile [3]. The basic source of information on economic processes running in the relevant company is the accounting system. The existing accounting modules, however, do not reflect the environmental aspects of the business processes. In the Czech Republic, the financial accounting module is firmly set by the relevant legislation. This, of course, does not prevent the business entities from tracking environmental aspects of their activities. Considering the main purpose of the financial accounting, i.e. to show true and fair picture of company business [4], we may assume that environmental issues should be reflected by this module. An important task regarding the presentation of environmental activities is also predicated to the managerial accounting module. It is desirable for managers to draw from this module information on material as well as financial attributes of selected environmental items. If these two accounting modules are adopted to give relevant environmental information, managers get a perfect information platform for their decision-making. Data obtained from environmental accounting modules are further analyzed by company managers using the system of environmental indicators. These indicators act as a good supplement to standard financial analysis, as they help to identify the current environmental profile of the company and discover potential problems that need to be solved. Environmental aspects are significant element of decisionmaking processes of business managers. They are reflected in decisions regarding investment activities, change of manufacturing program, improvement of competitiveness, improvement of relations with customers, etc. Should the contemporary management ignore or underestimate environmental footprint of its company (i.e. impact on company surroundings), the future may bring some serious problems with economy of the company. Without proactive approach to environmental protection, companies may lose their competitive advantage, suffer from financial problems with the fulfillment of strict environmental legislation and fail to create sufficient capital for modernization and innovation of their production processes.

\section{ACCOUNTING SUBSYSTEMS OF ENTERPRISES}

Accounting agenda of enterprises is an important information tool. Individual accounting modules provide enterprises with relevant information for their efficient financial management. Accounting modules supply complex information that may be used - most frequently in monetary form - to interpret economic effects and corporate processes [5].

Accounting information means an excellent and reliable information platform for enterprises not only for external users (investors, shareholders, suppliers, employees, customers, state authorities enforcing financial, tax or environmental policy, etc.), but also for internal users, respectively, enterprise managers in all levels of organization hierarchy as well [6]. Data taken from accounting books are processed by managers within the scope of financial analysis. With such information, they may easily assess the company performance, evaluate its financial situation and analyze other factors relevant for successful management of the company.

Users of accounting information have various requirements for data that can be obtained from accounting systems. Based on these requirements, various accounting modules are developed. Each module has its unique goals, works with different tools and with different statutory requirement.

Financial and managerial accounting systems are the basic modules of corporate accounting system. Companies that are concerned in their environmental profile complete these two modules by a relatively new one - environmental accounting module. Environmental accounting not only makes use of information from corporate financial accounting but also takes data and applies methods from managerial accounting. The required information is processed from the perspective of company environmental concerns. Individual accounting modules do not work separately - their functions are mutually interconnected and supplementing each other (see Fig. 1). 


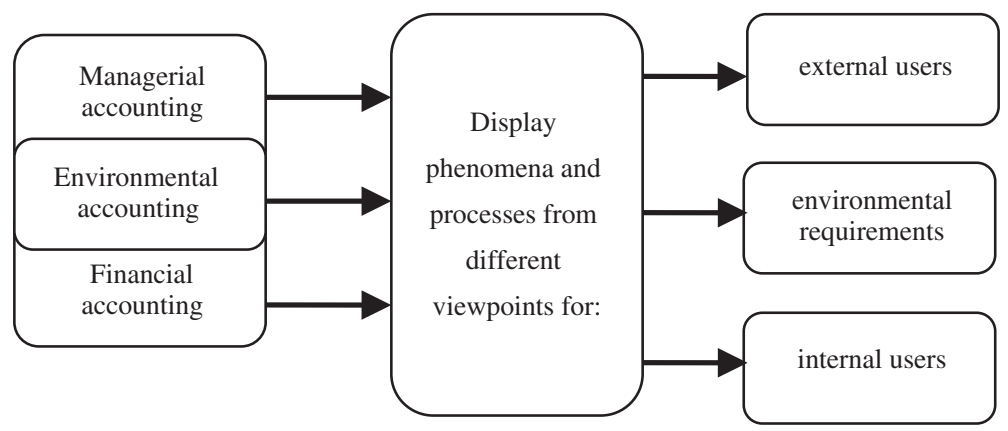

Figure 1: Accounting subsystems of enterprises. Source: Černíková and Malíková [7].

From the figure, it is obvious that two basic modules of financial and managerial accounting may be transformed into environmental accounting. The individual accounting modules differ by specific content, form and time orientation of information. Within their interaction, they create a sufficient platform for true and fair insight into the relevant company's economy.

\section{ENVIRONMENTAL ELEMENTS IN FINANCIAL AND MANAGERIAL ACCOUNTING}

The key task of financial accounting is to reflect economic effects and processes in the course of economic activity of a company in accordance with generally accepted accounting principles. At the end of accounting period, especially external users are provided with summarized information in the form of financial reports, including balance sheet, income statement and possibly also statement of cash flows and statement on changes in equity. Accounting system as well as general accounting rules must follow the framework principles. Such principles are embedded in national accounting legislation [8].

The current Czech legislation on accounting covers requirements for thorough monitoring of environmental aspects within the scope of corporate processes. Such monitoring may be realized with the help of analytic records, covering real accounts and even more nominal accounts. The traditional apprehension of financial accounting information is thus extended by environmental aspects. Company managers get more complex information that allows them to make more efficient business decisions, in compliance with requirements for sustainable development.

Companies in the Czech Republic track their environmental activities on a voluntary basis, especially using sub-ledgers (so-called analytic records). This means a certain risk for integration of environmental and standard financial accounting. As a consequence, environmental effects may not be tracked at required quality and scope of such monitoring may not be sufficient and transparent enough. The way of compiling financial report and required content are determined by act on accounting and the related implementing regulations. Environmental information is usually not directly included in the structure of financial statements (i.e. balance sheet and income statement) [9].

Environmental assets, liabilities, expenses and revenues are shown in financial report in a latent way. They are hidden on main ledgers (i.e. individual accounts of general ledger) and are not a standard part of financial statements, in accordance with the currently valid legislation. Information on environmental activities of a company is usually only covered in notes to financial statements, and monitoring of environmental activities from accounting point of view is voluntary for companies. This may result in biasing of some important accounting information for specific stakeholders. Inaccurate or hidden tracking of environmental information reduces quality of true and fair view of financial situation and performance of a company in connection with the effort to meet the requirements for sustainable 
development. This may in turn negatively affect financial analyses based on such inaccurate inputs. Final consequence may be inefficient financial management of business processes and negative impact on environment [10].

To present environmental activities within the scope of financial report, companies in the Czech Republic should accept recommendations of European bodies (European Commission). Accounting units in the Czech Republic having the obligation to verify their financial report by auditor must starting from 2004 - prepare their annual report in statutory scope. They must also include financial and non-financial information on their environmental activities. Even other companies often and voluntarily provide information on their environmental profile in notes to their financial statements. In the Czech Republic, this voluntary approach is mainly applied in branches with a significant impact on environment. The statutory regulations, however, do not specify accurately how environmental information should be structured in accounting systems or final accounts. Anyway, considering the fact that the basic principle of financial accounting is to provide true and fair insight in the company economic situation, environmental aspects are clearly an integral part of such requirement.

For the above reasons, financial accounting is not fully able to provide information on the environmental activities of the company. Environmental information (such as reduction of pollution, waste management, legal fees, insurance, fines, etc.) could be presented in the context of managerial accounting (usually in overhead categories - manufacturing or administrative). Managers of the company have a difficulty to identify them and thus, there is no feedback that would motivate responsible staff to manage and optimize these costs. The problem may also lie in an inaccurate allocation of environmental costs, which leads to wrong decisions of the management in promoting more environmentally friendly products (owing to a base of overheads distribution, environmental costs are incorrectly allocated on products that are not associated with damaging the environment) [7]. Some environmental costs are also not shown sufficiently, although they are significant (e.g. opportunity costs) and they may materially negatively affect the company's performance and its economic results [11]. Across the EU, and also in the Czech Republic, a new tool for monitoring environmental phenomena in the company is used in recent years that is called Environmental Managerial Accounting (EMA). It can help to resolve these problems [12].

EMA does not only provide information about significant environmental costs, but also provide significant impacts on the environment. For such decision tasks, it is necessary to identify and properly allocate environmental costs in the enterprise according to business needs [13].

Analysis of information from modules of environmental managerial and financial accounting creates a platform for exploring indicators of sustainable development, i.e. economic growth of the enterprise while respecting environmental factors [14]. After implementing environmental dimension, managerial accounting is capable of satisfying the needs of internal users, i.e. managers of the company [15].

\section{CASE STUDY: ENVIRONMENTAL ACCOUNTING SCHEME OF SELECTED ENTERPRISE - RESEARCH DATA}

For the purpose of this case study, internal data of the existing liability limited company, engaged in the sand mold aluminum casting, were used. The technology of aluminum casting is shown in Fig. 2.

By nature, the company production is classified as secondary manufacturing, as the company procures aluminum alloys as semi-finished product from big aluminum producers. The company processes about 15 tons of aluminum alloys a day. Considering the nature of its industrial processes, the company is considered as medium-sized polluter (according to the Act No. 86/2002 Coll., on Environmental Protection). Currently, the company does not fully track its environmental footprint in its accounting system. What the company's management has to consider according to act on 


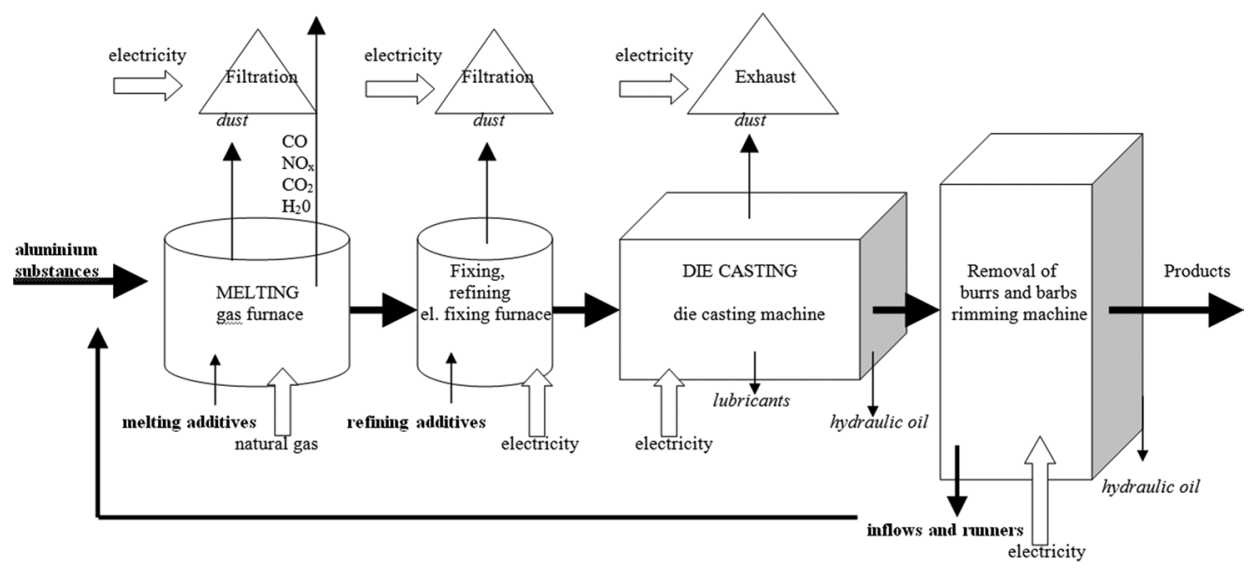

Remark: input materials are shown in bold letters, toxic outputs in italic letters

Figure 2: Technology flow of material in manufacturing of cast aluminum products. Source: Author's own elaboration.

environmental protection is the generation of physical non-product outputs (i.e. waste such as dust, used lubricants and hydraulic oil). Contrary to emission charges and costs for disposal of hazardous waste, these physical substances are not recorded in the company's accounting system. There is no system of environmental accounting in the company and the company also never pursued for ISO certification (e.g. EN ISO 14001 aimed at environmental management). To improve the environmental behavior of the company, the environmentally relevant aspects and items must be thoroughly monitored in the managerial as well as financial accounting. Should the management ignore or underestimate environmental footprint of the company and the related issues, the future may bring some serious problems (see Section 1 of this paper).

Therefore, the aim of this study was to come up with a basic platform for the establishment of the environmental accounting system. The work on this study may be divided into the following parts:

a. Analysis of selected entity inputs and outputs affecting the environment. These inputs and outputs were captured in the balance of material and energy sources within the managerial accounting module.

b. Suggestion of changes in the existing financial accounting module, so it may capture environmental aspects.

c. Preparation of a methodology for tracking of individual environmental impacts.

d. Introduction of the system of indicators used for comparison of environmental activities of business entities in selected period of time.

The cornerstone for tracking the environmental aspects of business is the establishment of the balance of material and energy flows, respectively the balance of inputs and outputs. Resource data for such balance may be obtained by analyzing the technology process of manufacture. As manufacture in the analyzed company is realized based on customer needs and requirements (and is - by its nature - considered as custom-made production), it would make no sense to quantify costs (or sales price) of one particular product. In managerial accounting, all data are tracked per 1 ton of input (output). This is how we present them hereinafter. 


\section{RESULTS AND DISCUSSION}

The following text brings our suggestions for reclassification of the existing modules of financial and managerial accounting in connection with the suggested tracking of environmental impacts of company activities.

According to internal data provided by the company and the prepared analysis of technology flow of materials in the company, we could come up with a basic scheme of balance of material and energy flows in the company in Euros (see Table 1). These data were determined based on technology procedures, management experience and information from financial and managerial accounting. The company neither classifies nor tracks them. It was not technically feasible to specify all items in physical units; therefore, the more convenient valuation in Euros was applied.

From Table 1, it is obvious that the basic materials for the manufacture of cast products are purchased aluminum semi-finished products. Besides them, the manufacture also consumes some auxiliary materials such as melting, refining and lubrication additives. Table 1 also shows information on consumption of energy. The output from production is represented by cast products required

Table 1: Proposal of balance of material and energy flows in the company engaged in aluminum Processing.

Inputs per 1 ton of products in $€$

\section{Base material}

Aluminum semi-finished products

$2,410.00$

Auxiliary materials

Melting additives

310.00

Refining additives

70.00

Lubricants

24.00

Energies

Gas

Electricity

120.00

Outputs per 1 ton of products in

Finished cast products

$4,320.00$

Non-product outputs

Melting dust

Refining dust

Die cast dust

Costs and charges for elimination of non-product outputs

Charges for emissions

Disposal of filter cartridges from melting and refining

12.00

Disposal of filter cartridges from die casting

Disposal of oil filter from die cast machine

0.50

Disposal of hydraulic oils

0.20

Other waste

1.00

Source: Author's own elaboration. 
by customers. Non-product outputs cover aluminum dust generated at aluminum melting, refining and die casting. The prices of these non-product outputs already cover filters (converted to 1 ton), electricity consumed for the operation of filtration system as well as material wasted in the form of dust caught by filters. The company must pay charges for emissions and for the hazardous waste disposal. The disposal works are carried out by professionals (external companies). 'Other waste' item covers various wastes that must be also disposed safely (oils, contaminated products, aluminum slag that cannot be recycled, etc.).

The balance in the table gives only the basic information on environmentally problematic items in the process of manufacture. To track these items consistently, it would be appropriate to adapt the accounting scheme (chart of accounts) of the company originally prepared for financial accounting purposes only. The following Table 2 shows the suggestion of changes in the company accounting system. Thus, it covers the required environmental data in order to allow for their regular monitoring and evaluation for the purposes of both internal and external users.

Table 2 suggests accounts to be used for the tracking of environmental balance sheet items and company expenses. It is obvious that most of the environmental activities will be reflected either as balance sheet items (Table 2 shows assets, but there are also some liabilities related with the relevant operations) or operations affecting the economic result (with regard to environmental burden, these will be most probably some costs and expenses of the company). As for non-product outputs, we may suggest their tracking on separate off balance sheet accounts in the financial accounting. The finishing of the cast aluminum product is first reflected as the increase in finished products stock in company balance sheet. The value equals to factory own costs. Upon realization (i.e. supply of finished product to customer, sale) of the product, the revenue is posted on the relevant account, amounting to sales price. In connection with this operation, the stock balance must be expensed accordingly (valued at own costs). Although in Czech Republic companies traditionally compile their income statement by the nature of costs expended, in this case we may recommend tracking the costs by their purpose.

Individual items should be tracked on a regular basis and used as a basis for ongoing evaluation of environmental activities of the company.

From the managerial accounting point of view, the time may not be the priority parameter monitoring of these activities may be aimed at individual orders, departments or responsibilities. Within the scope of financial accounting, companies compile their financial statements annually, at the end of the relevant accounting period. These financial statements and the relevant annexes are published, i.e. they become available also to external users. However, for the company's management purposes, it is necessary to assure that managers have the relevant data available at any time [16]. This may be assured by financial accounting system too, provided that the relevant activities will be tracked on individual analytical accounts. The usual tracking frequency is quarter or calendar month.

It is not only necessary to regularly track and document the relevant environmental aspects, we must also evaluate them using the appropriate system of indicators. The most common indicators are environmental complexity and efficiency. In general, environmental complexity indicators are structured as follows [17]:

$$
\operatorname{Env}_{\mathrm{n}}=\frac{\mathrm{ME}_{\mathrm{i}}}{\mathrm{V}}
$$

where $\mathrm{Env}_{\mathrm{n}}$ is the environmental complexity indicator, $\mathrm{ME}_{\mathrm{i}}$ the environmental $\mathrm{n}$-characteristic from the balance of material and energy flows and $\mathrm{V}$ the appropriate output variable. 
Table 2: Proposal for recording environmental aspects into the company chart of accounts.

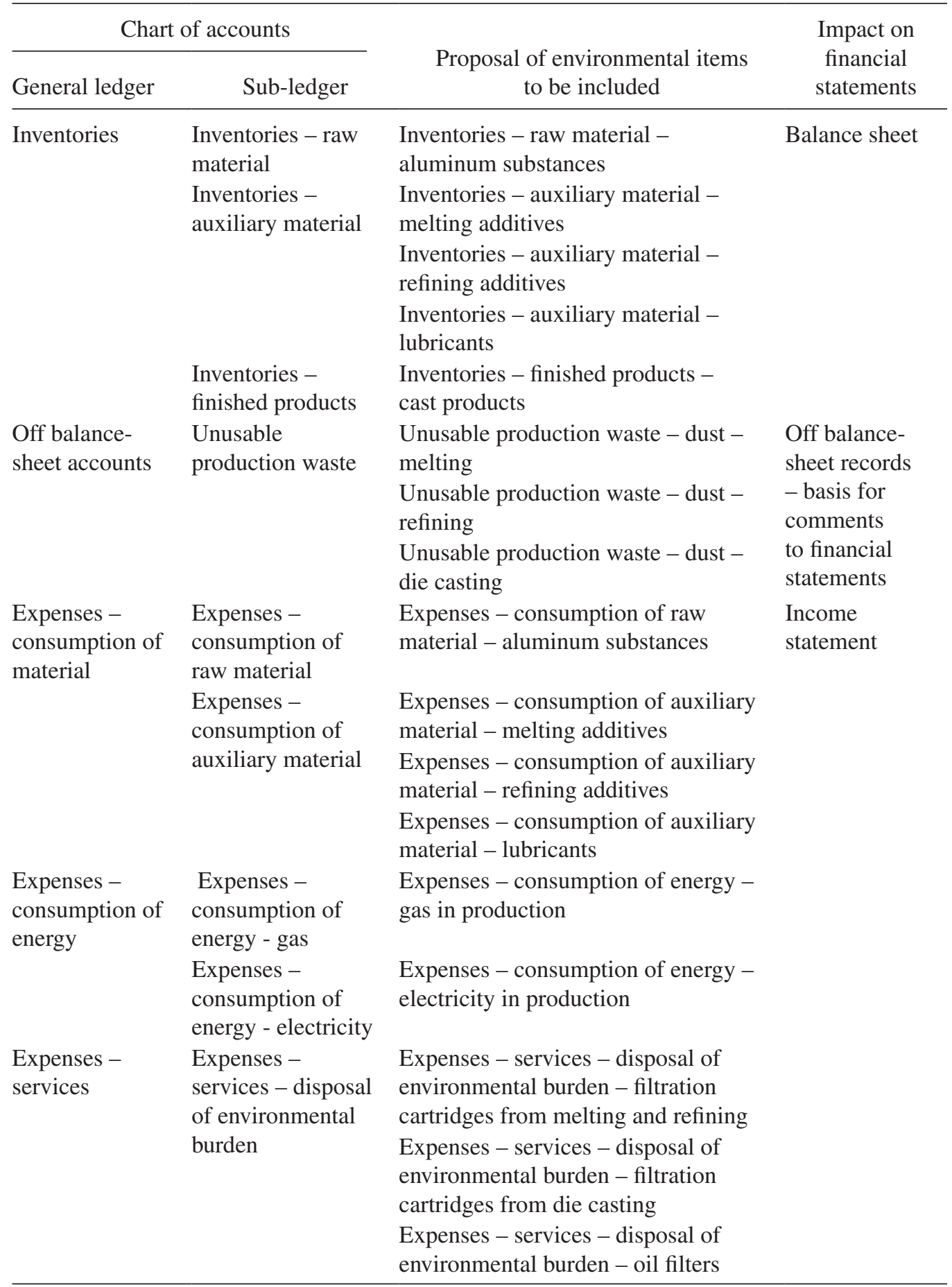


Table 2: (Continued)

\begin{tabular}{|c|c|c|c|}
\hline \multicolumn{2}{|c|}{ Chart of accounts } & \multirow{2}{*}{$\begin{array}{l}\text { Proposal of environmental items } \\
\text { to be included }\end{array}$} & \multirow{2}{*}{$\begin{array}{l}\text { Impact on } \\
\text { financial } \\
\text { statements }\end{array}$} \\
\hline General ledger & Sub-ledger & & \\
\hline & & $\begin{array}{l}\text { Expenses - services - disposal of } \\
\text { environmental burden - hydraulic oils } \\
\text { Expenses - services - disposal of } \\
\text { environmental burden - other waste }\end{array}$ & \\
\hline $\begin{array}{l}\text { Expenses - } \\
\text { taxes and fees }\end{array}$ & $\begin{array}{l}\text { Expenses - taxes and } \\
\text { fees - emission charges }\end{array}$ & $\begin{array}{l}\text { Expenses - taxes and fees - emission } \\
\text { charges }\end{array}$ & \\
\hline $\begin{array}{l}\text { Revenues from } \\
\text { sales }\end{array}$ & $\begin{array}{l}\text { Revenues from sales } \\
\text { - finished products }\end{array}$ & $\begin{array}{l}\text { Revenues from sales - finished products } \\
\text { - finished cast aluminum products }\end{array}$ & \\
\hline
\end{tabular}

Source: Author's own elaboration.

To determine the efficiency of environmental activities, we may use environmental efficiency indicators. They are also structured using the company balance of inputs and outputs and - in general - determined as follows:

$$
\operatorname{Env}_{\mathrm{u}}=\frac{\mathrm{V}}{\mathrm{ME}_{\mathrm{i}}}
$$

where $\mathrm{Env}_{\mathrm{u}}$ is the environmental efficiency indicator, $\mathrm{ME}_{\mathrm{i}}$ the environmental $\mathrm{n}$-characteristic from the balance of material and energy flows and $\mathrm{V}$ the appropriate output variable.

Environmental efficiency indicators [18] characterize relative decrease of material or energy inputs in relation to the increased reference indicator, such as profit, turnover, manufacture of specific product, etc.

Table 3 suggests indicators of environmental complexity that may be used to measure environmental activities in the analyzed company. The resource data may be also used for compilation of environmental efficiency indicators [19]. The data come from the company balance of material and energy flows as well as financial accounting (extended by environmental module). The output 'total number of cast aluminum products finished' (either in tons or $€$ ) was selected as the most appropriate denominator for the creation of relative indicators.

The analysis of the company relation to the environment is either carried out using absolute indicators (values in tons or Euro), or - when comparing the development of environmental activities with other entities over time - using relative indicators (see the last column in Table 3). The outcome is a coefficient or percentage that may be used to interpret the results. Through environmental activities, we can then strive after increase (or decrease) of such coefficient or percentage.

Using the system of indicators described above, we can measure the demand of manufacture of cast aluminum products as well as the consumption of auxiliary materials (melting, refining and lubrication additives and means). Energy consumption was determined as the consumption of electricity in $\mathrm{kWh}$ or gas consumption in $\mathrm{m}^{3}$ in relation to 1 ton of production (this may also be determined in $€$ ). Quite interesting is also tracking of non-product outputs (dust) and costs for fees and charges for emissions as well as costs associated with disposal of individual pollutants.

Currently, the company is not forced by any legislative tools to change its approach and because of rather successful undertaking (profitability is about 20\%), the company does not care about this 
Table 3: Proposal of absolute and relative indicators for aluminum processing company.

\begin{tabular}{|c|c|c|c|}
\hline \multirow[b]{2}{*}{ Inputs and outputs } & \multicolumn{2}{|c|}{ Absolute indicators } & \multirow[b]{2}{*}{$\begin{array}{l}\text { Possible relative } \\
\text { indicators }\end{array}$} \\
\hline & Physical units & $\begin{array}{l}\text { Recorded items as shown on } \\
\text { relevant account (in } € \text { ) }\end{array}$ & \\
\hline $\begin{array}{l}\text { Aluminum } \\
\text { substances }\end{array}$ & tons $(\mathrm{t})$ & $\begin{array}{l}\text { Inventories - raw material - } \\
\text { aluminum substances }\end{array}$ & $\begin{array}{l}\mathrm{t}(€) / 1 \mathrm{t}(€) \text { of } \\
\text { production }\end{array}$ \\
\hline Auxiliary materials & $\begin{array}{l}\text { kilograms, } \\
\text { liters }(\mathrm{kg}, \mathrm{l})\end{array}$ & $\begin{array}{l}\text { Inventories - auxiliary } \\
\text { material }\end{array}$ & $\begin{array}{l}\mathrm{kg}, 1(€) / 1 \mathrm{t}(€) \text { of } \\
\text { production }\end{array}$ \\
\hline Gas consumption & $\mathrm{m}^{3}$ & $\begin{array}{l}\text { Expenses - consumption } \\
\text { of energy - gas }\end{array}$ & $\begin{array}{l}\mathrm{m}^{3}(€) / 1 \mathrm{t}(€) \text { of } \\
\text { production }\end{array}$ \\
\hline $\begin{array}{l}\text { Electricity } \\
\text { consumption }\end{array}$ & $\mathrm{kWh}$ & $\begin{array}{l}\text { Expenses - consumption } \\
\text { of energy - electricity }\end{array}$ & $\begin{array}{l}\mathrm{kWh}(€) / 1 \mathrm{t}(€) \text { of } \\
\text { production }\end{array}$ \\
\hline Waste dust & $\mathrm{kg}$ & $\begin{array}{l}\text { Unusable waste from } \\
\text { production (off balance } \\
\text { sheet records) }\end{array}$ & $\begin{array}{l}\mathrm{kg}(€) / 1 \mathrm{t}(€) \text { of } \\
\text { production }\end{array}$ \\
\hline $\begin{array}{l}\text { Charges for } \\
\text { emissions }\end{array}$ & $\mathrm{mg} / \mathrm{m}^{3}$ & $\begin{array}{l}\text { Expenses }- \text { taxes and } \\
\text { fees }- \text { emission charges }\end{array}$ & $\begin{array}{l}\mathrm{mg} / \mathrm{m}^{3}(€) / 1 \mathrm{t}(€) \\
\text { of production }\end{array}$ \\
\hline $\begin{array}{l}\text { Charges - disposal } \\
\text { of filtration } \\
\text { cartridges }\end{array}$ & pc. & $\begin{array}{l}\text { Expenses - services - } \\
\text { disposal of environmental } \\
\text { burden - filtration cartridges }\end{array}$ & $\begin{array}{l}\text { pcs. }(€) / 1 \mathrm{t}(€) \text { of } \\
\text { production }\end{array}$ \\
\hline $\begin{array}{l}\text { Disposal of } \\
\text { lubricants and oils }\end{array}$ & 1 & $\begin{array}{l}\text { Expenses - services - } \\
\text { disposal of environmental } \\
\text { burden - hydraulic oils }\end{array}$ & $\begin{array}{l}1(€) / 1 \mathrm{t}(€) \text { of } \\
\text { production }\end{array}$ \\
\hline $\begin{array}{l}\text { Disposal - other } \\
\text { waste }\end{array}$ & pc., 1 & $\begin{array}{l}\text { Expenses - services - } \\
\text { disposal of environmental } \\
\text { burden - other waste }\end{array}$ & $\begin{array}{l}\text { pcs., } 1(€) / 1 \mathrm{t}(€) \\
\text { of production }\end{array}$ \\
\hline $\begin{array}{l}\text { Output - cast } \\
\text { aluminum product }\end{array}$ & $\mathrm{t}$ & $\begin{array}{l}\text { Revenues from sales } \\
\text { (possibly Inventories - } \\
\text { finished products) }\end{array}$ & - \\
\hline
\end{tabular}

Source: Author's own elaboration.

much. As for tracking the environmental aspects and activities, we recommended the management to deal especially with the selected areas shown in Table 4.

Table 4: Environmental aspects and activities.

1. Amortization of equipment used for manufacture of cast aluminum products

2. Wasted material (aluminum alloys) in the form of dust

3. Auxiliary materials (consumption of melting, refining and lubrication additives during manufacture)

4. Consumption of energies including wasted energy

5. Charges and taxes associated with environmental protection

(Continued) 
Table 4: (Continued)

6. Potential fines and sanctions due to some environmental damage

7. Costs associated with environmental monitoring of problematic manufacture

8. Costs for handling and keeping records of waste generated during manufacture

9. Labor costs associated with environmental protection (incl. health and social insurance)

10. Other costs associated with environmental care and protection (training of employees, obtaining ISO certification, etc.)

11. Analysis of potential costs for acquisition of integrated technologies aimed at prevention of pollution

12. Analysis of a chance of getting potential subsidies from state or EU budget to support cleaner manufacture

Source: Author's own elaboration.

The improvement of environmental behavior of the company based on the recommendations shown in Table 4 may be reflected in multiple so-called soft factors, such as [20]:

- increase of turnover, attractive for new customers;

- improvement of company's image by point of view of the public, better relations with customers, authorities and general public;

- reduction of environmental costs (lower risk of environmental damages, lower taxes and charges, lower insurance, etc.);

- higher creditworthiness in banks;

- higher motivation and work morale of employees, lower sickness rate and reduction of vocational diseases.

The above-mentioned changes and recommendations should also become a basis for future conception of accounting scheme (chart of accounts) of the company. By tracking and evaluation of environmental aspects of company business, the management of the company would get a new qualitative dimension. We can expect that in the future, the company will naturally and voluntarily assume tracking of its environmental processes. Otherwise, the company will be forced to do it, considering the development of international as well as national legislation in the field of environmental protection. However, the latter options mean some costs (fines for non-performance of stricter regulations, expenses associated with acquisition of cleaner technologies or forced innovation of manufacturing process). Such situation would obviously result in dramatic reduction of company's competitiveness - or even to its liquidation.

\section{CONCLUSIONS}

The sustainable development requirements, imposed by EU authorities on the member states, are also aimed at environmental protection. Therefore, the companies from EU countries must publish their environmental profile, especially those with high environmental burden.

Thorough monitoring of economic activities is the task for individual accounting modules. While the financial accounting system is only able to track values of past transactions, managerial accounting is able to flexibly follow intra-plant events (plans, budgets, product or project costs) by relevant departments or by responsibilities, as required by company managers, both in values and natural 
units. If the potential of these modules is fully utilized by managers, they may give the necessary information to mainly internal users literally at any time. The outputs from financial accounting are published yearly, following the end of the accounting period, even outside the company to external users as well.

It is obvious, from what is mentioned above, that tracking of environmental aspects within the scope of relevant accounting modules should not be a big deal for companies. We must, however, point out that financial accounting in the Czech Republic is subject to applicable legislation that except for companies that are obliged to compile financial statements (i.e. companies the financial statements of that must be audited by independent auditor) - does not stipulate the obligation to tract environmental aspects separately.

The supporting part of the paper is the case study that suggests establishment of an environmental accounting module in a specific company engaged in the manufacture of cast aluminum products, i.e. proposal for tracking and analyzing environmental transactions within the framework of managerial as well as financial accounting. Except for charges for emissions and costs for disposal of hazardous waste, the company does not track any other environmentally problematic aspects.

To develop the environmental accounting module, it is necessary to thoroughly analyze inputs and outputs affecting the environment. Such data obtained from the managerial accounting were further used for the adaptation of the existing chart of accounts, i.e. it was suggested to separately record within the scope of financial accounting - environmental transactions at sub- and off balance sheet ledgers level. Also, the methodology of their impact on financial reporting was described. Then, the system of indicators was developed to measure environmental activities of the company.

The suggested system of environmental accounting should help the company to expose problematic situations. Their early elimination could help the company to maintain its competitiveness and sustainable development. We can expect anyway, if the company refuses the model suggested on a voluntary basis, sooner or later it will adopt it being forced by local government or EU authorities.

\section{ACKNOWLEDGEMENTS}

This paper was originated in the scope of the research project 'Selected issues of financial management in the context of the current tax legislation' at the Faculty of Economics, Technical University of Liberec, with the financial assistance of its specific research (Students' grant competition) during the year 2013 .

\section{REFERENCES}

[1] Brigham, E.F., et al., Financial Management: Theory and Practice, 13th edn., South Western Cengage Learning: Mason, pp. 78-90, 2010.

[2] Burrit, R. \& Schaltegger, S., Sustainability accounting and reporting: fad or trend? Accounting, Auditing \& Accountability Journal, 23(7), pp. 829-846, 2010. doi: http://dx.doi. org/10.1108/09513571011080144

[3] Uneman, J., et al., Sustainability Accounting and Accountability. Routledge: New Edition, pp. 41-53, 2007.

[4] Malíková, O. \& Černíková, M., Environmental tools of atmospheric protection in the Czech Republic. WIT Transactions on Ecology and the Environment, 147, pp. 423-431, 2011.

[5] Nyquist, S., Accounting theory and financial environmental reports. Eco - Management and Auditing, 2000(7), pp. 178-185, 2000. doi: http://dx.doi.org/10.1002/1099-0925(200012)7: 4\%3C178::aid-ema136\%3E3.0.co;2-z

[6] Act No. 563/1991Coll., Accounting Act. 
[7] Černíková, M. \& Malíková, O., Environmental impact identified from company accounts in the Czech Republic. WIT Transactions on Ecology and the Environment, 179, pp. 695-702, 2013. doi: http://dx.doi.org/10.2495/sc130591

[8] Horák, J. \& Malíková, O., Environmentally related impacts on financial reporting: the case of pollution permits in Czech legislative conditions. WIT Transactions on Ecology and the Environment, 147, pp. 433-442, 2011. doi: http://dx.doi.org/10.2495/air110401

[9] Decree No. 500/2002 Coll., on accounting for entrepreneurs.

[10] Firoz, M. \& Ansari, A.A., Environmental accounting and international financial reporting standards (IFRS). International Journal of Business and Management, 10(5), pp. 105-112, 2010. doi: http://dx.doi.org/10.5539/ijbm.v5n10p105

[11] Burrit, R. \& Schaltegger, S., Contemporary Environmental Accounting, Greenleaf Publishing: Sheffield, pp. 85-112, 2000. doi: http://dx.doi.org/10.1016/s1066-7938(00)00098-1

[12] Albelda, E., The role of management accounting practices as facilitators of the environmental management. Sustainability Accounting, Management and Policy Journal, 1(2), pp. 76-100, 2011. doi: http://dx.doi.org/10.1108/20408021111162137

[13] United Nations. Environmental Management Accounting, Procedures and Principles, available at www.un.org/esa/sustdev/publications/proceduresandprinciples.pdf

[14] Burrit, R. \& Schaltegger, S., An Introduction to Corporate Environmental Management Striving for Sustainability, Greenleaf Publishing: Sheffield, pp. 58-72, 2003. doi: http://dx.doi. org/10.1108/meq.2003.14.4.541.4

[15] Morhardt, J.E., Baird, S. \& Freeman, K., Scoring corporate environmental and sustainability reports using GRI 2000, ISO 14031 and other criteria. Corporate Social - Responsibility and Environmental Management, 2002(9), pp. 215-233, 2002. doi: http://dx.doi.org/10.1002/ $\underline{\mathrm{csr} .26}$

[16] Jáčová, H., et al., New management systems and their application through ERP systems in the CR. Liberec Economic Forum, 2013(11), pp. 231-240, 2013.

[17] Balkema, A., et al., Indicators for the sustainability assessment of wastewater treatment systems. Urban Water Journal, 4(2), pp. 153-161, 2002. doi: http://dx.doi.org/10.1016/s1462$\underline{0758(02) 00014-6}$

[18] Morhardt, J.E., et al., Scoring corporate environmental and sustainability reports using GRI 2000, ISO 14031 and other criteria. Corporate Social - Responsibility and Environmental Management, 9(1), pp. 215-233, 2002. doi: http://dx.doi.org/10.1002/csr.26

[19] National Round Table on the Environment and the Economy, Eco-efficiency Indicators, 1st edn., Renouf Publishing: Ottawa, pp. 30-42, 2001.

[20] United Nations Conference on Trade and Development, A Manual for the Preparers and Users of Eco-efficiency Indicators, United Nations Publications: Geneva, pp. 106-109, 2003. 